\title{
The Chinese Struggle for Civil Rights in 19th-Century America: The Unusual Case of Baldwin v. Franks
}

\author{
Charles J. McClain Jr.
}

In its October term 1882, the United States Supreme Court handed down a decision which aborted federal efforts to deal with anti-black violence in the states of the old Confederacy. At issue in the case of United States $v$. Harris $^{\prime}$ was the constitutionality of a federal statute, Section 5519 of the Revised Statutes of the United States of 1874 , which made it a crime for private persons to conspire to deprive other individuals of the equal protection of the laws. A group of white Tennesseeans had been convicted under the statute for assaulting and badly beating a group of black criminal defendants in the custody of local authorities. The court held that there was no foundation in the Constitution for the federal law and voided it, thus overturning the convictions. The 14th Amendment, the purported basis for the statute, was aimed, according to the court, at state action and did not empower Congress to legislate against purely private conduct. It was the same line of reasoning that would lead the court in its following term, in the celebrated Civil Rights Cases, ${ }^{2}$ to declare unconstitutional Section 1 of the Civil Rights Act of $1875,{ }^{3}$ which established civil and criminal penalties for

Charles J. McClain, Jr., is Vice Chairman of the Jurisprudence and Social Policy Program and Lecturer in Law at the School of Law (Boalt Hall), University of California, Berkeley. I am very indebted to Professor Paul Mishkin of the School of Law (Boalt Hall), and to Professor Ling-Chi Wang of the Asian American Studies Department, University of California, Berkeley, and to my wife, Professor Laurene Wu McClain of City College of San Francisco, for reading and commenting on an earlier draft of this article. I wish also to acknowledge the assistance I received from Ms. Robyn Dondero, formerly an archivist with the Federal Archives and Records Center, San Bruno, California. Finally I owe a great debt of gratitude to Ms. Cynthia Fox, Archivist with the National Archives and Records Service, who went to much trouble to find and copy for me numerous records from Department of Justice files. This article is part of a larger work-in-progress on the Chinese contribution to the shaping of American legal history.

1. 106 U.S. 629 (1883).

2. 109 U.S. 3 (1883).

3. Civil Rights Act of 1875 , Sec. 1, 18 Stat. 335. 
racially motivated interference with anyone's full and equal enjoyment of public accommodations and conveyances.

Four years after the decision in Harris, a most remarkable criminal proceeding was launched in the United States Circuit Court for the District of California. It was aimed at reviving the statute rendered moribund by the Supreme Court in Harris and employing its provisions to protect another embattled racial minority, the Chinese residents of the Western United States. The proceeding, which eventually went up to the United States Supreme Court for review under the case name of Baldwin v. Franks, ${ }^{4}$ rested on a novel and imaginative legal theory, and the case is fascinating even purely from a doctrinal standpoint. In the entire history of the Supreme Court there cannot have been many instances in which the tribunal, years after the event, seriously considered the contention that a statute it had flatly declared to be null and void might in fact be salvageable. But the case is far more interesting from a legal- and social-historical standpoint for the added light it throws on the outlook and attitudes of the Chinese community in nineteenth century America, and perhaps, too, as we shall see later, on the history of modern Chinese diplomacy.

The Chinese have been a neglected group in American historiography. When they have been written about, it has generally been exclusively in terms of the reaction their presence in the western states provoked in the majority Caucasian population. Scholarly attention that has focused on the Chinese has tended to depict them as a people without interest in the larger social and political milieu ${ }^{5}$ who, in the words of one of the leading historians of nineteenth-century California 'suffered with helpless stoicism whatever indignities were thrust upon them' ${ }^{6}$ Such an interpretation is wide of the mark. There is abundant evidence that the leaders of the Chinese community in America were, from the earliest days of the immigration and throughout the nineteenth century, well attuned to the larger political milieu and that they consistently displayed shrewdness and intelligence in operating in that milieu. I have described elsewhere ${ }^{7}$ how during what I have designated the first phase of the immigration, the period 1850-1870, the Chinese leadership responded often and publicly to racist demagoguery, how they regularly voiced their grievances in the legislature of the State of California, the state where the vast majority lived, and how they succeeded in persuading the

4. 120 U.S. 678 (1887).

5. See, e.g., Gunther Barth, Bitter Strength, A History Of The Chinese In The United States, 1850-1870 (Cambridge, Mass., 1964); K.Y. 20, Chinese Emigration (New York, 1971).

6. Robert Glass Cleland, A History Of California: The American Period (New York, 1922), 416; quoted with approval in Elmer Sandmeyer, The Anti-Chinese Movement In California, Illini Books Ed. (Urbana, 1973), 24.

7. Charles McClain, 'The Chinese Struggle for Civil Rights in Nineteenth-Century America: The First Phase, 1850-1870' 72 California Law Review 529 (1984). 
federal Congress to include, in effect, a Chinese civil liberties provision in a major Reconstruction-era civil rights statute. ${ }^{8}$

It was in the courts however, that the Chinese demonstrated most impressively their political sensibility. At an early date they recognized how courts could be used to control the Sinophobic impulses of the Caucasian majority and they learned to repair to them when their interests were threatened. In the 1860's, for example, they used the courts to blunt the impact of a discriminatory California tax imposed only on Chinese gold miners $^{9}$ and to nullify another tax aimed at other classes of Chinese laborers. ${ }^{10}$ In later years they were successful in persuading the courts to overturn, among other discriminatory enactments, a San Francisco ordinance aimed at humiliating Chinese prisoners in the county jail by requiring that their queues be shorn off, " a California law forbidding Chinese from fishing in the state's waters, ${ }^{12}$ a whole series of city ordinances aimed at making it impossible for Chinese laundrymen to carry on business, ${ }^{13}$ a San Francisco ordinance designed to ghettoize Chinese residents in one of the least desirable parts of the city ${ }^{14}$ and another law that in effect required only Chinese residents to submit to innoculation with an experimental bubonic plague serum. ${ }^{15}$ These cases, it may be noted, were of substantial importance in the shaping of American Constitutional jurisprudence, a fact that has gone largely unnoted by legal historians. ${ }^{16}$

Baldwin v. Franks, a Chinese-sponsored legal action, fits, in most respects, into the pattern of nineteenth-century Chinese civil rights litigation, but it has features which make it strikingly different as well. It may be the most unusual of the Chinese civil rights cases especially when viewed in light of events transpiring in Western America in the mid-1880's.

8. Sec. 16 of the Civil Rights Act of 1870. Ch. 114, Sec. 16, 16 Stat. 140, 144 (1869-71). For background on the enactment of the provision see ibid.

9. See Ex parte Ah Pong, 19 Cal. 106 (1861) and Ah Hee v. Crippen, 19 Cal. 491 (1861). Discussed in McClain, supra note 7 at 558-559.

10. Lin Sing v. Washburn, 20 Cal. 524 (1862), discussed in McClain, supra note 7 at 555-57.

11. Ho Ah Kow v. Nunan, 12 Fed. Cases 252 (1879).

12. In re Ah Chong, 2 Fed. Rep. 722 (1880).

13. See, e.g., In Re Quong Woo, 13 Fed. Rep. 229 (1882); In re Tie Loy, 25 Fed. Rep. 611 (1886); In re Sam Kie, 31 Fed. Rep. 680 (1887).

14. In re Lee Sing et al., 43 Fed. Rep. 359 (1890).

15. Wong Wai v. Williamson, 103 Fed. Rep. 2 (1900).

16. At least in any published work. For a remarkably comprehensive survey of nineteenthcentury Chinese civil rights cases see Hudson Janisch, The Chinese, The Courts And The Constitution, unpublished J.S.D. dissertation, (Chicago, 1971). 


\section{The Anti-Chinese Hysteria of 1885-1886}

Outbursts of violence against the Chinese marred American history from the very beginnings of the Chinese immigration, ${ }^{17}$ but it is probably fair to say that anti-Chinese violence reached its apogee in North America in the mid-1880's. The fall of 1885 was a season of special ferocity. In September 1885 , one of the worst race riots in nineteenth-century American history took the lives of twenty-eight Chinese laborers in the frontier town of Rock Springs, Wyoming and left the Chinese section of town destroyed. ${ }^{18}$ In the same month three Chinese residents of Squak Valley in Washington Territory were killed in a large vigilante attack on their rural campsite. In early October a hostile, unruly crowd invaded the Chinese section of Seattle and threatened the inhabitants. In November mob action forced all Chinese out of the neighboring city of Tacoma. ${ }^{19}$ These were the most serious incidents, but there were lesser, alarming occurrences of anti-Chinese violence elsewhere in the west throughout the fall of 1885 and into the winter of $1886 .{ }^{20}$ Even when there was no outright violence, there were threats and intimidation. The main newspapers of Washington, Oregon, and California were filled with reports of mass meetings, in towns and hamlets of every size, where menacing resolutions were passed demanding that the Chinese be expelled from the town limits. ${ }^{21}$ It is no exaggeration to say that a kind of

17. See Roger Daniels ed., Anti-Chinese Violence In North America (New York, 1978). In 1871 a race riot in Los Angeles took 19 Chinese lives. See William R. Locklear, 'The Celestials And The Angels: A Study Of The Anti-Chinese Movement In Los Angeles To $1882^{\prime}$, in Daniels, reprinted from Historial Society of Southern California Quarterly, xlii (1960) 239-56.

18. Paul Crane and Alfred Larson, 'The Chinese Massacre', Annals of Wyoming, xii ( 1940) 47-55, in Daniels, supra note 17. See also the copious and detailed documentation of the incident prepared under auspices of the Chinese consulate in San Francisco, in H.R. Exec. Doc., 49th Cong. 2nd Sess. Vol. 1, Foreign Relations of the United States, (1886), pp. 109-47.

19. See W.P. Wilcox, 'Anti-Chinese Riots in Washington', Washington Historical Quarterly, XX (1929) 204-12 and Jules Karlin, 'The Anti-Chinese Outbreaks in Seattle', Pacific Northwest Quarterly, xxxix (1948) 103-29, and Karlin, 'The Anti-Chinese Outbreak in Tacoma', Pacific Historical Review, xxiii, (1954) 271-83. All in Daniels, supra note 17.

20. See, e.g., Sacramento Daily Record Union, Feb. 23, 1886, reporting raid on the Chinese quarter of Oregon City, Oregon; Sacramento Daily Record Union, March 7 , 1886, reporting expulsion of Chinese from Mt. Tabor, near Portland.

21. See, e.g., reports of anti-Chinese demonstrations in Truckee, California which forced the discharge of all Chinese from employment. Sacramento Daily Record Union, Jan. 18, 1886; Daily Alta California, Feb. 14, 1886. Accounts of mass meetings can be found in virtually every issue of the major San Francisco and Sacramento dailies from December, 1885 to March, 1886. On March 2, 1886 the U.S. District Attorney for Oregon, Lewis McArthur, wrote to the Attorney General in Washington, D.C.: 'Large bodies of men, presumably citizens of the United States, have in nearly every town and village throughout the state organized themselves into societies whose object, as near as I can ascertain, is to expel the Chinese from our limits'. Department of Justice Year File 980-84, Number 1659. 
mass hysteria was sweeping through the white populace which seemed aimed at nothing less than the removal of the Chinese from all settled human habitation in the Pacific States.

Representatives of the Chinese community in America reacted with anguish to these events and sought to pressure national authorities to protect Chinese residents of the western states and territories. The pogrom in Rock Springs provoked a major diplomatic confrontation between the Department of State and the Chinese legation in Washington, D.C. ${ }^{22}$ Protests and pleas for help followed quickly on the heels of the other major incidents as well. In the wake of the first Washington disturbances Frederick A. Bee, an American businessman who served as a representative of the Chinese Six Companies, an umbrella organization of associations representing the various districts around Canton from which the Chinese immigrants came, ${ }^{23}$ and as Vice Consul at the Chinese consulate in San Francisco, telegraphed the governor of Washington Territory, expressing fear that another Rock Springs might break out in his jurisdiction and demanding greater protection for the Chinese. ${ }^{24}$ Similarly, after the Tacoma riot, the Chinese minister to Washington contacted Secretary of State Thomas F. Bayard asking that immediate countermeasures be taken ${ }^{25}$ including the initiation of legal action against wrongdoers.

22. See H.R. Exec. Doc. Nos. 64, 67, 49th Cong. 2nd Sess. Vol. 1, Foreign Relations of the United States, (1886), pp. 101-47, 158-68. See also Shih-shan Henry Tsai, China And The Overseas Chinese In The United States, 1868-1911 (Fayetteville, 1983), 72.77 .

23. There were several well demarcated districts in the Canton area, the region of China from which most nineteenth-century immigrants came; and identification with and loyalty to the district of origin were deeply ingrained in the inhabitants. When the Chinese arrived in California, they organized into district associations. These associations performed a variety of tasks, including aiding new immigrants in their search for employment and collecting debts owed to persons still in China. It would not be too far off the mark to describe them as benevolent and fraternal societies.

In the early 1860's, a coordinating council of the California district associations was organized. One of its main jobs was to adjudicate disputes between Chinese from different districts, but it came quickly to serve, as well, as chief intermediary between the Chinese community and the larger white society. Each district organization was represented on the council, and the council presidency rotated among the heads of the various district associations. At various times as few as four and as many as eight district associations were represented, but the organizations became popularly known as the Chinese Six Companies. The Six Companies was unquestionably the most important organization in Chinese America in the nineteenth century. For background on the Six Companies, see William Hoy, The Chinese Six Companies (San Francisco 1942). See also Barth, Bitter Strength supra note 5 at 96-100; 'The Six Chinese Companies', 1 Overland Monthly I (1868), 221-27. Later, in a period beginning about 1870 and continuing through the end of the century, the Six Companies sponsored a great deal of what can accurately be described as Chinese civil rights litigation.

24. H.R. Exec. Doc., No. 137, 49th Cong., Ist Sess., Vol. 1, Foreign Relations of the United States (1885), p. 194.

25. Ibid. Doc. No. 142, p. 196. 
As the disorders spread in the late fall and early winter, Chinese pleas became more urgent. (On February 7, 1886 a Seattle mob again invaded the Chinese quarter and routed the Chinese out of their homes.) On February 13, 1886, Lee Kim-wah, President of the Six Companies, telegraphed the Chinese legation in Washington, '. . . the condition of our countrymen on this coast is deplorable in the extreme. The Chinese have been driven out of many towns, the people burning our dwellings, robbing our property and murdering our people [with impunity]' ${ }^{26}$ He beseeched the Minister to contact the President to demand that federal troops be sent to protect the Chinese. Several days later the Chinese minister called on Secretary Bayard and laid before him a batch of telegrams and newspaper clippings from California, which lent credence to the Six Companies' view that a concerted effort seemed to be afoot in the state to drive the Chinese out of all of its towns and cities. ${ }^{27}$

National governmental authorities came part of the way toward meeting Chinese demands. Grover Cleveland's administration dispatched an army escort to Rock Springs in the wake of the riot to protect Chinese representatives who were conducting an investigation. In the midst of the Washington disturbances President Cleveland issued an ultimatum to the territory's white inhabitants threatening to send troops if the disorders did not cease. ${ }^{28}$ In his first annual message to Congress, Cleveland adverted to Rock Springs and other anti-Chinese riots in the west and declared that 'All the power of [the federal government] should be exerted to maintain the amplest good faith toward China ...., and inflexible sternness of law in bringing the wrongdoers to justice should be insisted upon'. ${ }^{29}$

What the national government would not do, however, was to admit that it had any responsibility, or any right, to go any further. Representatives of the Chinese legation had from the very outset of the anti-Chinese violence of the 1880's insisted that the national government, as opposed to the states, had ultimate responsibility for the safety of Chinese residents in America and was bound to take positive steps-including the initiation of legal action against wrongdoers - to assure the protection of Chinese lives and property. The legation also claimed that the national government was under a duty to provide monetary compensation to the anti-Chinese riot victims. These claims were invariably rebuffed by the U.S. Government. It denied any

26. Text of the telegram can be found in Sacramento Daily Record Union, March 8, 1886.

27. Sacramento Daily Record Union, Feb. 17, 1886.

28. Proclamation by President Grover Cleveland under date of Nov. 7, 1885. H.R. Exec. Doc., 49th Cong., 1st Sess., Vol. 1, Foreign Relations of the United States (1885), pp. $197-98$.

29. James D. Richardson, Messages And Papers Of The Presidents, 1789-1897, viii, 329 (Washington, D.C. 1898). Three months later he sent a special message to Congress elaborating on the same theme and asking the body, as a gesture of good will, to make an appropriation for the payment of compensation to the victims of the Wyoming massacre. Message of March 1, 1886. Richardson, viii at 383-86. 
liability to compensate riot victims, insisting that the prosecution of criminal misdeeds of the sort complained of was, because of the American federal system of government, a matter exclusively within the jurisdiction of state authorities. ${ }^{30}$ When Cleveland spoke of bringing wrongdoers to justice, he had in mind the actions of local, rather than federal, officials.

From the Chinese perspective this was an entirely unsatisfactory state of affairs. Local authorities might prosecute ordinary criminal acts directed at individual Chinese from time to time. But given the temper of the times in the West, it seemed to the Chinese entirely unrealistic to expect local authorities to use municipal law to blunt what were in effect the manifestations of a quasi-political movement enjoying wide societal supportespecially when these local authorities were themselves more often than not

30. The Chinese and American positions were first set out in a diplomatic exchange concerning a riot in Denver in the fall of 1880 that took one life and destroyed a considerable amount of property. To a request from the Chinese Minister that the U.S. government provide compensation for property losses and see that the guilty parties were arrested then Secretary of State William Evarts replied that the American government had no responsibility to indemnify the victims and was powerless to take action against the wrongdoers. 'The powers of direct intervention on the part of this Government [in the affairs of a state] are limited by the Constitution', he wrote. 'Under the limitations of that instrument, the Government of the Federal Union cannot interfere in regard to the administration or execution of the municipal laws of a State of the Union'. H.R. Exec. Doc. No. 188, 47th Cong., 1st Sess., Vol. 1, Foreign Relations of the United States, (1881), p. 319. The Chinese Minister, Ch'en Lau Pin, replied to Evarts that the case seemed different to him since it involved individuals who were present in this country under the explicit provisions of a treaty negotiated between China and the general government of the United States. 'The case under consideration', he wrote, 'should be a question of intercourse between China and the United States, and different from that to be dealt with under the ordinary internal administration of a State. It was with this view that I had . . . requested you to cause this case to be examined'. H.R. Exec. Doc. No. 190, 4th Cong., 1st Sess., Vol. 1 (1881) p. 322. See also letters of Nov. 30, 1885 and Feb. 15, 1886 from the Chinese Minister Cheng Tsao-ju to Secretary of State Thomas F. Bayard and Bayard's reply to Cheng of Feb. 18, 1886 in respectively H.R. Exec. Doc. Nos. 64, 65, 67, 49th Cong., 2nd Sess., Vol. 1, Foreign Relations of the United States (1886), pp. 101-09, 154-56, 158-59. These letters concerned Rock Springs and other disturbances of 1885-86. The Chinese Minister insisted that the national government take direct and forthright measure to end what he called the reign of terror among his countrymen. 'It does not become me to indicate that these measures should be. Neither is it my province to consider the internal relations of Government or the workings of the domestic laws of this country'. he wrote. It just seemed to him that the national government was both empowered and obliged to do something. Letter of Feb. 15, 1886, Doc. No. 65. Bayard reaffirmed the hands-off position of his predecessor Evarts.

On the establishment of the first Chinese legation in the United States and on the early history of U.S.-China diplomacy, see Kenneth W. Rea, ed., Early Sino-American Relations, 1841-1912: The Collected Articles Of Earl Swisher, (Boulder, 1977); Delber L. McKee, Chinese exclusion versus the Open Door Policy, 1900-1906 (Detroit, 1977); Worthy of special mention are two excellent recent monographs: S.H. Tsai, China And The Overseas Chinese In The United States, supra note 22, and Michael Hunt, The Making Of A Special Relationship. The United States And China To 1914 (New York, 1983). Both provide important new insight into the relationship between the Chinese government and the Chinese community in the United States. 
in the movement's vanguard. ${ }^{31}$ The Chinese felt that the national government was both empowered and bound to do more than it was doing. Their frustration at the inaction of the national authorities grew as anti-Chinese incidents multiplied.

\section{The Incidents in Nicolaus and Oregon City}

Sacramento, California and its environs had long been a focus of anti-Chinese sentiment. The city and outlying towns were close to the mining regions where the anti-Chinese movement had originated. Furthermore, as state capital, Sacramento had served for years as a principal forum for the Sinophobic politics of the era. Each session of the legislature witnessed the introduction of new anti-Chinese legislation and a flow of anti-Chinese rhetoric. Demonstrations, mass meetings, public resolutions, outbursts of vigilantism-all aimed at isolating or expelling the hated Chinese minority - were the order of the day in Sacramento and neighboring communities in the winter of $1885-1886.32$

The tiny town of Nicolaus lies about 25 miles northeast of Sacramento. In the late nineteenth century much of Nicolaus' agricultural land was given over to the growing of hops, and a fair number of Chinese workers were employed in the industry. Like practically every hamlet in California it had its anti-Chinese club. On the 6th of February, 1886 the club notified the Chinese workers on five hop farms just outside of town that they had ten days to leave the vicinity or suffer serious consequences. When the Chinese refused to comply with the ultimatum, a group of local vigilantes decided to make good on the threat. At three in the morning on February 18, a band of masked men visited the hop ranches in question, broke into the residences of some forty-six Chinese hop-workers, forced them out of their beds, and drove them to a wharf on the Feather River, where the steamer Knight was lying at anchor loading wheat. At this point accounts of the incident become fragmentary and confused, but it appears that the white citizens of Nicolaus had raised a sum of money to pay fares on the steamer and sought to negotiate passage with the vessel's captain. The captain refused to accept money for his unwilling passengers but at length agreed to take them on

31. Washington territorial authorities to their credit, did take rather forthright steps to deal with the anti-Chinese disturbances. The perpetrators of the Squak Valley killings were prosecuted for murder. Also, the governor of the territory declared martial law in the wake of the February riot in Seattle. For an interesting discussion of the treatment of Chinese litigants by the courts of the Pacific Northwest during this period see John $R$. Wunder, 'The Chinese and the Courts in the Pacific Northwest: Justice Denied?', Pacific Historical Review lii (1983) 191-211.

32. In early January a resolution was introduced before the City Trustees, calling for a ban on Chinese residence within the city limits. It was not enacted but the fact that it was seriously debated is an index of the tenor of the times. See Sacramento Daily Record Union, Jan. 12, 1886. 
board and ferry them out of the area. They were put on a barge that the steamer was towing, to the great amusement and applause of a crowd of onlookers, and at midafternoon were disembarked down river in the state capital. ${ }^{33}$

Four days later a remarkably similar incident occurred in Oregon City, Oregon, a town on the outskirts of Portland. There too a band of masked marauders raided the Chinese quarter in the middle of the night, rousted them from their homes and forced them aboard a riverboat bound for Portland. ${ }^{34}$ These were acts of out-and-out brigandage, rivaling in contempt for law some of the grosser outrages then being perpetrated in the southern states by the Ku Klux Klan and its allies. They were too, from the Chinese perspective, yet another challenge to the ability and determination of the United States to see to it that aliens residing on its soil under treaty rights were protected from mob violence.

On February 21, Ching-Ping, Chinese Vice Consul at San Francisco, and his secretary, in the company of a Deputy U.S. Marshal, visited Nicolaus and conducted interviews. The next day the two Chinese arrived in Sacramento. The Vice Consul reported that he had been in the course of a visit to Red Bluff and other towns to inquire into anti-Chinese disturbances in those locales when the events at Nicolaus had occurred. While in the state capital he sought to make arrangements for the Nicolaus refugees. One gathers from the newspaper reports of his stay in Sacramento that he was quite upset about what had happened in Nicolaus and elsewhere and that he was frustrated that the law was not more quickly coming to his aid. ${ }^{35}$ His frustration must have intensified when news of the February 22 outbreak in Oregon City reached him. And it was perhaps at this point that the decision was made, probably by Chinese diplomatic representatives in conjunction with local Chinese leaders to seize the initiative. In short order two legal actions were undertaken which, in effect, forced the hand of the national government on the question of federal responsibility for harms inflicted on the Chinese in the states of the west. ${ }^{36}$

\section{Initiation of Criminal Proceedings}

The Chinese of the Portland area retained a Portland law firm, one of whose members was the former U.S. District Attorney for the state, to assist them in the initiation of criminal proceedings against the perpetrators of the

33. Sacramento Daily Record Union, Feb. 19, 1886.

34. See The Enterprise, Oregon City, Oregon, Feb. 25, March 4, 1886.

35. See, e.g., Sacramento Daily Record Union, Feb. 23, 1886. He told a reporter that if he had officers to accompany him, he would take the illegally evicted Chinese back to Nicolaus.

36. Although direct evidence is lacking, it is rather difficult to believe that the two actions were not part of a coordinated strategy. 
Oregon City outrage. ${ }^{37} \mathrm{~A}$ complaint was filed, arrests were made, and on March 2, Judge Matthew Deady, Federal District Judge for Oregon, summoned a grand jury. The Portland action was soon upstaged, however, by a parallel criminal proceeding beginning to unfold in California.

On March 8, 1886, there appeared in the Sacramento courtroom of B.N. Bugby, a Commissioner of the Circuit Court of the United States for the District of California, one John Sing, an erstwhile resident of Nicolaus. He swore out a complaint charging Thomas Baldwin, a native of Nicolaus, and some fifteen other white men of conspiring to expel him and a number of fellow Chinese from the town and thereby to deprive them, as the complaint put it, of their right to the equal protection of the law. ${ }^{38}$ On the basis of this complaint Bugby issued a warrant charging Baldwin and his confreres with the unspecified crime of conspiracy and directing the U.S. Marshall to take them into custody. On March 12, Deputy U.S. Marshall J.C. Franks arrived in Nicolaus, arrested the accused and took them immediately back to Sacramento. ${ }^{39}$ They were brought before Commissioner Bugby the next day for an initial appearance, and March 16 was set as the date for preliminary examination.

News about the arrests spread quickly, and on March 16, a large crowd jammed Commissioner Bugby's officer for the hearing. The accused retained former Attorney General A.L. Hart and Grover Johnson, a leader of the California Anti-Chinese Movement, to represent them. (Coincidentally, two mammoth state Anti-Chinese Conventions, in one of which Johnson was playing a significant part, were underway in the state capital at this time.) There was no official U.S. government representative present, but a private attorney, A.C. Hinkson, of the Sacramento firm of Armstrong and Hinkson, a firm clearly under retainer to the Chinese, appeared to state the case against the accused. The official warrant for the arrest of the accused had spoken only of the general crime of conspiracy. It now emerged for the first time that the specific federal statute they were accused of violating was Sec. 5519 of the Revised Statutes of 1874, the federal law which made it a crime for individuals to conspire to deprive others of their right to the equal protection of the law but which had been declared unconstitutional by the U.S. Supreme Court in U.S. v. Harris. ${ }^{40}$

37. See letter from Lewis L. McArthur, U.S. Attorney for Oregon, to the Attorney General of the United States, March 2, 1886; Department of Justice Year File 980-84, No. 1659.

38. See case file In re Baldwin, File 3989, Federal Archives and Records Center, San Bruno, $\mathrm{Ca}$.

39. Sacramento Daily Record Union, March 13, 1886.

40. The inspiration for using section 5519 came, in all probability from events in Washington Territory. The previous November, W.H. White, United States Attorney for the Territory, acting entirely on his own initiative, had secured several grand jury indictments under the section against anti-Chinese rioters. (See Department of Justice Year File 980-84 Docs. 2017, 2437, 2856, 9497, 9733, 9858.) Direct evidence is lacking, but one may speculate with some confidence that White's theory in proceeding under the section rested on an important dictum in The Civil Rights Cases 109 U.S. 3 
Needless to say, a bitter debate ensued about the legitimacy of the accused's internment. Johnson and Hart demanded their clients' immediate release. To buttress their demand they produced a telegram from S.G. Hilborn, the U.S. Attorney in San Francisco, under the same day's date, informing them that Judge Lorenzo Sawyer intended to telegraph Commissioner Bugby that Sec. 5519 was unconstitutional. The strong implication was that he would also shortly direct the Commissioner to drop the case. 'If case not promptly dismissed', Hilborn wired, 'Get continuance and I will attend to it'. ${ }^{41}$ The argument on the other side was rather weak. Hinkson made reference to Article VI of the Burlingame Treaty, which assured to Chinese living in the United States the same privileges and immunities with respect to residence and travel as those enjoyed by citizens of the most favored nation, but he did not elaborate very compellingly on how this provision worked to salvage an unconstitutional statute. ${ }^{42}$

Commissioner Bugby could not have helped but be impressed with the strength of the defendants' argument but indicated he was not disposed to dismiss the case without specific instructions from Judge Sawyer. They were not to come. Later in the hearing another telegram to Hart and Johnson from U.S. Attorney Hilborn disclosed that Judge Sawyer had elected simply to call Bugby's attention to the section's unconstitutionality, without mandating any particular outcome to the proceeding. Bugby determined that he would not dismiss the charges and remanded the defendants to the custody of the U.S. Marshal. ${ }^{43}$

\section{Habeas Corpus Hearings}

Events now began to move quickly. The lawyers for the accused, no doubt as a precaution, had filed a petition for a writ of habeas corpus in

(1883). The constitutional issue under review in those cases, it will be recalled, was almost identical to the issue in Harris, namely the extent to which Congress could legislate against purely private conduct. While the court held that Congressional power was quite limited when it came to the private conduct of individuals within the states, it declared that Congress had plenary power to pass legislation in every branch of municipal regulation' when it came to the territories 109 U.S. 3, 19, and the court in fact intimated that the legislation it was in the process of voiding insofar as it applied to the state might well pass constitutional muster as applied to the territories. (Both the legislation under review in The Civil Rights Cases and Sec. 5519 applied to the acts of individuals 'in any state or territory'.)

It was one thing to seek to invoke the section in a federal territory, quite another to attempt to invoke it in the states where the Supreme Court had said with apparent finality it could have no application.

41. No one in the United States Attorney's office had been consulted about either the filing of the complaint or the issuance of the arrest warrant. See letter of Hilborn to Attorney General Garland, Apr. 5, 1886. Department of Justice Year File 980-84, No. 2498.

42. Best account of the argument is to be found in the Sacramento Daily Record Union, March 17, 1886.

43. Ibid. 
Sawyer's court the previous day and on the 16th of March a writ issued, returnable March 18. Not content with this avenue of relief, however, they decided to pursue a parallel course in the state courts. On the next day, the 17th of March, they filed an application for a habeas writ in Sacramento Superior Court. Judge Van Fleet issued the writ, returnable the same day, but on hearing oral argument, decided that the case came within the rule of the pre-Civil War case of Ableman v. Booth ${ }^{44}$ which had held that no state court could issue a writ of habeas corpus to release prisoners held in Federal custody, and that he was without authority to consider the matter further ${ }^{45}$ The stage was now set for the hearing of the federal petition.

On the afternoon of March 18, Deputy Marshal Franks, accompanied by a, one might guess, reluctant U.S. Attorney Hilborn, produced the body of one Thomas I. Baldwin before Judge Lorenzo Sawyer. (Attorneys for all sides had previously agreed that all of the Nicolaus defendants save one should be released and that one should be allowed to represent the class.) Hilborn was the nominal representative of the U.S. government, but it quickly emerged that the real responsibility for the conduct of this litigation on the government side now rested with private attorneys in the employ of the Chinese community ${ }^{46}$ Hilborn engaged in some preliminary sparring with counsel for the petitioners on the form of the habeas petition but had nothing to say on the merits. Vice Consul Bee, on the other hand, was present in court and informed the court that he had retained the well known San Francisco attorney, Hall McAllister, to represent the Chinese interest in the case but that McAllister's business engagements prevented him from being present. He asked that the hearing on the merits of the petition be postponed until the following week when McAllister could appear. The request was granted. ${ }^{47}$

The retention of McAllister by the Chinese made it clear that they viewed the Nicolaus case as one of large significance and of potentially rich legal returns. Hall McAllister stood at the pinnacle of the California legal profession. ${ }^{48} \mathrm{He}$ was, beyond doubt, the greatest courtroom advocate of the era and stands out even today as one of the most impressive lawyers in the history of the California bar. He had for many years conducted a flourishing

44. 21 How. (62 U.S.) 506 (1859).

45. Sacramento Daily Record Union, March 18, 1886.

46. Throughout the proceedings Hilborn was to remain little more than a semi-cooperative bystander. The fact that from beginning to end this criminal case was under the management and control of private attorneys was never raised as an issue by counsel for the other side.

47. Various accounts of the March 18 hearing are to be found in the San Francisco Bulletin and The Evening Post of that date and in The Morning Call (San Francisco) and Sacramento Daily Record Union of March 19, 1886.

48. For information on McAllister's life and career see Oscar T. Shuck, History Of The Bench And Bar Of California (Los Angeles, 1901), 417; and obituary notices published in San Francisco newspapers on the occasion of his death, Dec. 2, 1888. 
practice in San Francisco, numbering among his clients such business interests as the Pacific Mail Steamship Company and the Central Pacific Railway and such prominent individuals as Leland Stanford and members of the Spreckels family. His name dots the state's law reports, and there were few major appellate cases decided in the latter part of the nineteenth century in which he did not play a role. He was, coincidentally, at the moment under retainer to the Chinese laundrymen's guild in its challenge to a San Francisco ordinance that was making it impossible for Chinese laundry operators to carry on their trade. The ordinance was to be nullified two months later in the landmark equal protection opinion, Yick Wo $v$. Hopkins. ${ }^{49}$ McAllister's trademarks as a lawyer were a commanding presence in the courtroom and a legal mind of exceptional agility. The latter quality was much in evidence in the habeas hearing that took place on March 30 in the courtroom of the Circuit Court of the United States for the District of California before Circuit Judge Lorenzo Sawyer and District Judge George Sabin.

Here for the first time the theory of the case against the Nicolaus conspirators was set forth in full detail. To be sure, McAllister conceded, the United States Supreme Court in U.S. v. Harris had overturned the conviction of a group of defendants who had been prosecuted under section 5519 of the Revised Statutes and in the process had declared the statute itself to be beyond the power of Congress to enact. But, McAllister contended, the court had voided the statute only insofar as it purported to apply to actions of citizens of the United States against other U.S. citizens. In Harris the court had simply said that the ordinary criminal acts of one citizen against another were, under prevailing notions of federalism, the peculiar province of the states and could not be brought under the jurisdiction of the national government either on 13th, 14th, or 15th Amendment grounds. (These were the supposed constitutional bases of the statute according to the attorneys for the government in Harris.)

In the instant case, McAllister went on, the prosecution of the petitioners under Sec. 5519 rested on a wholly different set of constitutional premises. It was firmly established, he noted, that the national government had plenary powers to enter into treaties with foreign governments and that these treaties once concluded were the supreme law of the land. It was equally clear that under the 'necessary and implied powers' clause of the Constitution (Art. I, Sec. 8) Congress had full power to pass legislation in implementation of agreements concluded by the national government. The United States had concluded treaties with the Chinese empire in 1868 and again in 1880 which had given subjects of China the right to reside and carry on trade in the United States, had secured to them 'all rights, privileges, immunities, and exemptions' enjoyed by the citizens of the most favored nation, and had further pledged the United States, should Chinese residents meet with ill treatment at the hands of other persons, to 'devise measures' to 
protect them and to secure the aforesaid rights. Here, declared McAllister, was ample constitutional basis for the application of Sec. 5519 to the conspiracy in question in the case before the court. The statute could be viewed, post hoc, as it were, as a measure taken in discharge of U.S. treaty obligations. McAllister did not contend that Congress had had the Chinese in mind in enacting sec. 2 of the Civil Rights Act of 1871, the source from which Sec. 5519 derived - such a claim would have found no support in the statute's legislative history-but that was not crucial to the argument. $\mathrm{He}$ seemed rather to be operating on the well accepted principle that a law general enough in its terms could have unforeseen beneficiaries. ${ }^{50}$

For good measure, although he did not press the matter, McAllister threw in two other provisions of the Revised Statutes of 1874 which he claimed sanctioned a conspiracy prosecution against the Nicolaus group: Secs. 5508 and $5336 .{ }^{51} \mathrm{Sec} .5508$ made it a federal crime for two or more persons to conspire to injure or oppress any citizen in the exercise of any right secured by the U.S. Constitution or for two or more persons to go in disguise on the highway or in the premises of another for the purpose of hindering him in the free exercise of rights so secured. Sec. 5336 punished, among other things, conspiracies to hinder the federal government in the execution of its laws. (Both of these issues were to be forcefully argued on appeal. At this stage of the proceeding, however, they were distinctly in the background.)

Former Attorney General Hart, for the petitioners, vigorously contested this argument. Congress could not limit the powers of a state over ordinary criminal offenses, he declared, by the adoption of a treaty. If the McAllister argument were accepted, then in his view, it must follow that every crime or offense committed against a Chinese person in any state would have to be tried in a federal court. According to Hart, tortured and specious logic was being offered to try to salvage an obviously void and unconstitutional law. There appears to have been little questioning from the bench during oral argument and thus little indication from the judges as to the direction in which they might be leaning. But at the conclusion Circuit Judge Sawyer promised that the court would render its decision the next day. ${ }^{52}$

A large crowd assembled in Judge Sawyer's courtroom on March 31. Conspicuous in it were a number of the leaders of the Chinese community. A reporter had commented in the previous day's Evening Post: 'The Chinese are basing high hopes on the result. . . . If the prayer for the writ is denied and the petitioner remanded, it will open the way to retaliatory arrests in every town in the state from which the Chinese have been evicted. ${ }^{53}$ Sawyer sounded a similar note in the half-hour opinion which he read in

50. The Evening Post (San Francisco), March 30, 1886; Daily Alta California, Sacramento Daily Record Union, March 31, 1886.

51. These sections had also been used in the Washington prosecutions, supra note 40 .

52. Sacramento Daily Record Union supra note 45.

53. The Evening Post (San Francisco), March 30, 1886. 
open court. ${ }^{54}$ The issue before the court, he declared, was "one of vast consequence to the entire Chinese population of the United States, and of the utmost importance to the peace and good order of society throughout the entire Pacific Coast." ${ }^{55}$. Paying scant heed to the other sections of the Revised Statute being offered as basis for the prosecution, he went straight to section 5519 which he correctly recognized as the heart of the Chinese case.

If this section ... is valid as to Chinese subjects residing in the United States, and embraces the acts set out in the petition and return, then the acts of all public meetings throughout the land looking to, and providing for, depriving Chinese subjects of the rights, privileges, immunities, and exemptions secured to them . . . by means popularly known as 'boycotting', or any other coercive means, no matter in what form, or through what channels applied, are criminal, and all those participating in them must be subject to the very severe penalties denounced by the statute. ${ }^{56}$

Sawyer found that the section did in fact apply to the Chinese and that as so applied it was saved from Constitutional infirmity. Sawyer was persuaded by McAllister's argument concerning the availability of the treatymaking power as constitutional basis for the application of the enactment to the Chinese. The national government's treaty-making power was broad indeed, Sawyer affirmed, and easily comprehended the subject matter of the several treaties the United States had entered into with the Chinese Empire. These agreements secured to the Chinese a large array of rights, privileges and immunities. That among these rights were the right to select a place of residence and to pursue a lawful vocation at the place so selected seemed unarguable to him. (Sawyer relied heavily on an earlier opinion of his own ${ }^{57}$ for the proposition that the right to pursue a lawful vocation was among the privileges secured to the Chinese by treaty.) He attached especial importance to Art. 3 of the Treaty of 1880 which provided:

If Chinese laborers, or Chinese of any other class, now either permanently or temporarily residing in the territory of the United States, meet with ill treatment at the hands of any other persons, the government of the United States will exert all its power to devise measures for their protection, and to secure to them the same rights, privileges, immunities, and exemptions as

54. The full text of the opinion was published in most San Francisco newspapers the next day. See, e.g., Daily Alta California, The Morning Call, April 1, 1886. The official report appears in 27 Fed. Rep. 187 (1886). Citations here are to the official report.

55. 27 Fed. Rep. 187, at 192-93.

56. Ibid. at 193.

57. In re Tiburcio Parrott, 1 Fed. Rep. 481 (1880). The case overturned a portion of the California Constitution and implementing legislation making it unlawful for California corporations to employ any Chinese laborers. 
may be enjoyed by the citizens of subjects of the most favored nation, and to which they are entitled by treaty. ${ }^{58}$

Here two points stood out. First, the national government had voluntarily assumed the obligation to take-if we may use a contemporary term'affirmative action' to secure Chinese rights, privileges and immunities. And secondly, it had undertaken to secure these rights against invasion not only by unfriendly state legislation but as well by individual persons. Section 5519 and the prosecution in the Nicolaus case could be seen as the government's discharge of the obligation it had undertaken by solemn international compact. Thus, he concluded, 'The case of the Chinese residents of Nicolaus is clearly distinguishable from that of United States citizens arising under the Fourteenth Amendment, considered in the case of U.S. v. Harris ${ }^{59}$ and rests upon other and further provisions of the national constitution'. 60

As to the argument advanced by counsel for the petitioner that if the Chinese view were accepted-namely, that they were protected by federal law against ordinary criminal acts-then this represented a severe undermining of the presumed state authority over its own citizens, Sawyer countered that the state had not in this instance surrendered power over its own citizens in their dealings with each other but had only surrendered its power over the intercourse of its citizens with foreign nationals, a legitimate subject of national concern. And, Sawyer emphasized, this was a perfectly rational policy. 'It is presumed that the state will protect its own citizens,' he observed, 'while long experience shows that it will not always protect foreigners against the prejudices and hatred of citizens'. ${ }^{61}$

Sawyer recognized, however, that he now confronted an additional problem. It could be argued with great plausibility that Congress had the power under the constitution to pass a law limited in its terms to protecting Chinese aliens resident in the United States in their treaty rights. Moreover, forgetting for the moment about actual legislative intent, it might plausibly even be argued that the protection of Chinese could be seen as coming under the general language of R.S. Section 5519. What clearly could not be maintained, however, was that section 5519 was limited to the protection of Chinese rights and privileges. The statute clearly embraced other things as well, and it was precisely these other things that had caused the statute to fail constitutional muster in U.S. v. Harris. ${ }^{62}$ The question therefore now arose whether the inclusion of improper subject matter in the statute had vitiated the statute for all purposes. Or could the constitutional be separated from unconstitutional parts of the law?

58. 22 Statutes at Large 827.

59. Supra note 1.

60. In re Baldwin, 27 Fed Rep. 187, 191 (1887).

61. Ibid. at 189.

62. Supra note 1. 
The U.S. Supreme Court had scarcely dealt with the issue of statutory separability or severability before the Civil War but had handed down a number of important opinions on the question in the immediately preceding decade. Sawyer touched on most of these-lightly, it must fairly be said-in his analysis. The case on which he most heavily relied was Packet Co.v. Keokuk. ${ }^{63}$ In this 1878 opinion the high tribunal had sustained against challenge on commerce clause grounds a city ordinance of Keokuk, Illinois which provided for the charging of fees to vessels moored on the city's wharves on the Mississippi River. Conceding that the ordinance as drafted was subject to a broad interpretation, which would make it constitutionally infirm (it charged fees for docking on the unimproved river bank as well as at the city's wharves), the court chose to give it a narrow interpretation, which brought it well within the bounds of constitutionality. The court had said in Keokuk: 'Statutes that are constitutional in part only, will be upheld so far as they are not in conflict with the constitution, provided the allowed and prohibited parts are severable' ${ }^{64}$ Sawyer read the case as standing for the proposition that courts ought to go out of their way to find such severability of parts, and he did not experience too much difficulty in finding it in section 5519 so far as it applied to the case at bar. The key was the ethnic distinctness of the Chinese.

Chinese subjects residing in the United States constitute a separate, distinct, independent class, with distinctly defined and easily recognized limits; and it is not readily perceived why the class may not be easily segregated, and the provisions of the statute held constitutional and valid and be fully enforced as to that class, even though void as to other persons and classes, relying on other provisions of the constitution, easily recognized, and without difficulty segregated. ${ }^{65}$

Sawyer recognized, however, that he was not on the firmest of grounds in reaching this determination. There was authority supportive of the view that courts ought not to go out of the way to carve constitutional enclaves out of statutes that were in the aggregate unconstitutional and that the principle of severability ought to be sparingly applied. He was frank in acknowledging this. But he felt constrained, he said, to resolve doubts in favor of the validity of the statutes as it was sought to be applied in the instant case. ${ }^{66}$ Sawyer noted that his associate, Judge Sabin, 'though with doubt and hesitation', dissented from his ruling, and he assured counsel that a 'certificate of division of opinion' ${ }^{67}$ would be made and a writ of error

63. 95 U.S. 80 (1878).

64. Ibid. at 89 .

65. In re Baldwin, 27 Fed. Rep. 187, 191 (1887).

66. Ibid. at 194.

67. Sec. 6509 of the Revised Statutes of 1874 provided that when upon the trial or hearing of a criminal proceeding before a circuit court, a point occurred on which the judges were divided in opinion, the point of disagreement, upon motion of either party, should be certified to the Supreme Court for authoritative decision at its next session. 
allowed to the U.S. Supreme Court if either party desired it. Indeed he practically invited such a motion. This was a matter which ought quickly, authoritatively and finally to be determined by the Supreme Court. "The specific questions now presented are questions of too vast consequence to be finally determined by a subordinate court', he declared. If a writ of error was taken, he added, the prisoner would be allowed to go at large on his own recognizance. In the meantime he suggested that the government not prosecute 'other similar cases' until an authoritative decision could be had. ${ }^{68}$ Following upon Sawyer's suggestion, a joint request for a certificate or division of opinion was made by both sides. The request was granted, and the prisoner Baldwin was freed on his own recognizance.

Sawyer sent the case record and opinion on to the Department of Justice with a plea that it be docketed and submitted at the Supreme Court's present term. 'I can imagine no case that so urgently requires prompt action', he wrote. 'This whole coast is inflamed by active men who are organizing to perpetrate similar outrages. If there is any law making such action criminal, it ought to be authoritatively declared. . . . ${ }^{69}$ Stipulation was obtained from counsel to place the case immediately on the Court's calendar and to submit it for decision on the basis of written briefs. ${ }^{70}$ Within a month the matter was briefed and under submission.

\section{The Argument on Appeal}

Former Attorney General A.L. Hart did not deal with the severability question at all in his argument to the high court. His brief on appeal simply re-stated the position which counsel for the Nicolaus detainees had repeatedly made in the proceedings below. Section 5519 of the Revised Statutes of the United States, under which the plaintiff-in-error was being prosecuted was unconstitutional and void for all purposes. The subjects upon which Congress could legislate were clearly specified in the Constitution. Upon these it could legislate generally without reference to the persons whose rights it sought to protect. Upon other subjects, however, it could not legislate at all. Conspiracies by private persons against other private persons lay beyond the reach of Congressional power. Such conspiracies as well as the underlying offenses were the exclusive preserve of the states. Nor had the conclusion of treaties with China changed the picture. 'It was not intended [by the Burlingame Treaty]', Hart declared, 'to create the possibility of two systems of municipal law, the one passed by Congress and enforced in the Federal Courts and applicable to Chinese alone; the other

68. In re Baldwin, 27 Fed. Rep. 187, 194-95 (1887). The 'other similar cases' referred to the prosecutions then underway or under consideration in Washington and in Oregon.

69. Letter from Lorenzo Sawyer to A.H. Garland, Attorney General, April 5, 1886. Department of Justice, Year File 980-84, Doc. No. 2497.

70. Ibid. Document No. 2559. 
passed by the Legislatures of the States, enforceable in the State courts and applicable to citizens as well as aliens'. ${ }^{71}$ Acceptance of the opposite view by the court would amount to an endorsement of the position that it was possible, by entering into a treaty, to change the nature and form of the American government, a manifest absurdity.

McAllister took an interesting tack in his argument. As noted earlier, in the proceedings below, he had raised the question of the applicability of two other federal laws, Secs. 5508 and 5336 of the Revised Statutes, to the Nicolaus incident. But the argument had not been pushed very far and discussion of the provisions had been completely overshadowed by the debate on Sec. 5519. (In his opinion Sawyer had devoted a scant few lines to them without reaching any firm conclusions.) McAllister now chose to highlight these statutes and to press vigorously for their applicability. His analysis of them consumed the first two thirds of this brief.

Sec. 5508, derived from anti Ku Klux Klan legislation enacted in $1870,{ }^{72}$ provided for the punishment of those who conspired 'to injure, oppress, threaten, or intimidate any citizen in the free exercise or enjoyment of any right or privilege secured to him by the Constitution or laws of the United States' and of those who went in disguise on the highway, or on the premises of another with intent to hinder the exercise of such rights. There was no question about the statute's constitutionality, and, relying on the premise that the right to reside on American soil and to pursue a peaceful avocation were federal rights secured to the Chinese by the several treaties with China (by the laws of the United States, in other words), McAllister submitted that the actions of the Nicolaus mob were on their face a violation of the statute's terms. ${ }^{73}$ Sec. 5336 derived ultimately from the Act of July 31 , 1861, a measure passed in the wake of the Southern secession. ${ }^{74}$ It provided for the punishment of those who conspired to overthrow the government of the United States or 'to oppose by force the authority thereof' or "by force to prevent, hinder, or delay the execution of any law of the United States'. Conspiracies to deprive the Chinese of their treaty rights were in effect conspiracies to prevent, hinder or delay the execution of federal laws, in this case treaties, he contended. And here he was able to call to his aid the authority of a well known and highly respected member of the federal bench. A few months previous, U.S. District Judge Matthew Deady had specifically instructed the federal grand jury for the District of Oregon, which was ready to hear cases against the Oregon City anti-Chinese rioters, that conspiracies to drive the Chinese from their rightful place of residence

71. Brief on Behalf of Petitioner, p. 20.

72. Act of May 31, 1870, Vol. 16, Statutes At Large, p. 141.

73. Brief for Respondent, pp. 15-18.

74. Act of July 31,1861, Vol. 12, Statutes At Large, p. 284. Re-enacted in Act of April 20, 1871, vol. 17, Statutes At Large, p. 13. 
amounted to attempts to prevent the execution of federal laws and came within the terms of Sec. $5336 .{ }^{75}$

On the question of Sec. 5519's constitutionality, McAllister did little more than embellish on the argument which he had made to Judge Sawyer, founding authorization for the statute on the treaty-making provisions of the original Constitution. The Harris case, he argued, had addressed a completely separate issue and ought to be limited as authority to the single point it decided. And he cited the authority of the great constitutional commentator Thomas Cooley for the proposition that a legislative act might be clearly void as to some categories of cases and clearly valid as to others. ${ }^{76}$

\section{The Supreme Court Decision}

Despite the pleas for urgent action, it was not until almost a year later that the Supreme Court rendered its decision. Chief Justice Waite delivered the opinion of the Court March 7, 1887. At the outset he conceded the validity of a major point advanced by counsel for the Chinese. He was fully convinced of Congress' plenary power to legislate to protect Chinese interests in this country. 'That the United States have power under the Constitution to provide for the punishment of those who are guilty of depriving Chinese subjects of any of the rights, privileges, immunities or exemptions guaranteed to them by ... treaty, we do not doubt', he wrote. ${ }^{77}$ What the court had to decide, however, according to Waite, was not whether Congress could legislate to protect the Chinese but whether it had in fact done so in the sections of the Revised Statutes under consideration. ${ }^{78} \mathrm{He}$ addressed each section in turn, giving most attention to Sec. 5519 , which, as he noted, was clearly the main basis for the prosecution. ${ }^{79}$

The court was not persuaded by McAllister's attempt to salvage the section for the purpose of protecting the Chinese. To be sure, the court accepted the principle that a statute could be in part constitutional and in part unconstitutional and that the constitutional part might be capable of enforcement. But such would be the case, in the court's view, only where the parts were so distinctly separable that each could stand alone and where the court could find that the intention of the legislature was that 'the part pronounced valid should be enforcible, even though the other part should fail'. ${ }^{80}$ The

75. Brief for Respondent, supra note 73 at $18-22$. At the same time Deady denied the applicability of Sec. 5519 and did not instruct the grand jury on this section. See The Enterprise, Oregon City, Ore., March 25, 1886.

76. Brief for Respondent, supra note 73 at 29-33.

77. Baldwin v. Franks, 120 U.S. 678,683 (1887).

78. Ibid. at 682 .

79. Ibid. at 684 .

80. Ibid. at 689, quoting Virginia Coupon Cases, 114 U.S. 269 at 305 (1885). 
problem with section 5519 was that it had no parts. "A single provision, which makes up the whole section', Waite wrote, 'embraces those who conspire against citizens as well as those who conspire against aliens. . . . ${ }^{81}$ The case of United States $v$. Reese $e^{82}$ offered guidance on the question. There two Kentucky election inspectors had been indicted under Secs. 3 and 4 of the Civil Rights Act of 1870, which punished voting inspectors for any wrongful refusal to receive the votes of citizens. There was nothing in either section to limit its operation to wrongful refusals to accept votes on the basis of race or color, which was clearly within the power of Congress to do, and for this reason they were held to be void. They were too broad in their coverage, comprehending subject matter that was both within and without the jurisdiction of the Congress. The court there had refused to limit the statute by construction so as to make it operate only on that which Congress might rightfully prohibit, holding that to do so would be 'to make a new law, not to enforce an old one'.

Packet Co. v. Keokuk, the case on which Sawyer had relied to find severability, ${ }^{84}$ presented a problem for this line of reasoning. There, as in Reese, one had a single statutory provision, broad enough to be applied in constitutional and unconstitutional fashion, but the court had allowed the ordinance to stand. But for Waite the crucial distinction was that Keokuk involved the contestation of a civil ordinance regulating wharfage fees and not a penal statute ${ }^{85}$ Apparently stricter application of the severability test was appropriate when penal laws were in question.

With respect to Sec. 5519, one final point needs noticing. The court commented that it had not been called upon to decide and was not deciding whether Sec. 5519 was separable to the extent that it could be enforced in a territory even though it could not be enforced in a state. ${ }^{86}$

The court found that Secs. 5508 and 5336 were simply not applicable. By its language Sec. 5508 punished those who conspired to injure or intimidate citizens in the exercise of their rights, but in its second part it used ostensibly more general language, making it a crime to go on the premises 'of another' with intent to hinder his free exercise of federally protected rights. According to Waite the second part was of a piece with the first and was limited in its application to wrongs committed against citizens, which the Chinese clearly were not. ${ }^{87}$ As to Sec. 5536, which made it a crime to interfere by force with the execution of any law of the United States, the court held that to come under the section force must be brought to bear directly against the

81. Ibid. at 685 .

82. 92 U.S. 214 (1875).

83. Ibid. at 221, quoted with approval in Baldwin, 120 U.S. at 686.

84. See text supra at pp. 365-66.

85. Baldwin, 120 U.S. at 688-99.

86. Ibid. at 685 .

87. Ibid. at 690-92. 
government, the application of force against private individuals in frustration of federal governmental purposes being insufficient. ${ }^{88}$

Justices Harlan and Field dissented from the majority opinion. Harlan was convinced of Sec. 5508's applicability. The use of the term 'another' instead of 'citizen' in the latter clause of the section, he wrote, showed that in respect of the rights and privileges seemed by the section, Congress had in mind the protection of persons whether citizens or not. (In this sense the section's language was a little like that of the Fourteenth Amendment.) Baldwin and his confederates had certainly gone 'on the premises of another' with the intent to interfere with rights secured by the law of the land. ${ }^{89}$

Field, albeit somewhat tentatively, associated himself with Harlan's interpretation, but he preferred to found his dissent on Sec. 5336. It was a powerful and plausible one. The third clause of that section, which punished conspiracies by force to prevent the execution of any law of the United States was clearly applicable in his view. The stipulations of the various treaties with China, guaranteeing to Chinese aliens in this country the rights of residence and labor, were in his view the law of the land, operating by their own force and requiring no further legislative action for their enforcement. 'The right or privilege being conferred by the treaty', he went on, 'parties seeking to enjoy it take whatever steps are necessary to carry the provisions into effect. . . . Those who wish to reside here select their places of residence, no congressional legislation being required [to put their rights into effect]. . . . All that is needed, is such legislation as may be necessary to protect them in such enjoyment ${ }^{9}{ }^{90}$ And that, according to Field, they had in Sec. 5336's provision punishing conspiracies to hinder by force the execution of federal laws. The Nicolaus conspirators well knew, as everyone did, that Chinese aliens were guaranteed the rights of residence by solemnly executed national compact. Their actions were aimed not just at their particular victims but at Chinese as a class. Their purpose was to nullify the rights conferred on this class of persons by a treaty executed by the national government. What could be a clearer case of a conspiracy against the supremacy and authority of the United States. ${ }^{91}$ Field sounded an alarming note at the end of his opinion:

'The result of the decision', he wrote, 'is that there is no national law which can be invoked for the protection of the subjects of China in their right to reside and do business in this country, notwithstanding the language of the treaty with that empire.... Their only protection against any forcible resistance to the execution of these stipulations in their favor is to be found in the laws of the different states. Such a result is one to be deplored' ${ }^{92}$

88. Ibid. at 692-94.

89. Ibid. at 694-98.

90. Ibid. at 704 .

91. Ibid. at 705 .

92. Ibid. at 707 . 
Press reaction to the Baldwin decision was varied. Several Eastern papers, while not objecting to the decision, took Congress severely to task for not passing laws to protect the Chinese, commenting that it was vain to expect that they could secure protection from the Western states. ${ }^{93}$ Needless to say, the opinion stirred lively comment on the Pacific Coast, some of it sympathetic to the Chinese cause. The Sacramento Daily Record Union, for example, a Republican paper which like all organs of opinion on the coast was urging severe restrictions on Chinese immigration but which was terrified of vigilantism and mob violence, deplored the decision, commenting that Justice Field had stated the correct view of things. ${ }^{94}$ The Daily Alta California, a like-minded journal, also supported Field's dissent but added that Congress should pass laws to make good on its treaty obligations to the Chinese. ${ }^{95}$ Perhaps more consonant with general public opinion was the editorial which appeared the day after the decision in the San Francisco Evening Post. 'This decision is a subject for congratulation, without regard to the merits of the particular case involved', wrote the Post, heaving a giant sigh of relief as it were that the judicial branch was at last beginning to turn a deaf ear to Chinese complaints. 'It is desirable, of course, that affairs like that at Nicolaus should be prevented', the paper continued, 'but it is not desirable that United States courts should have a confirmed habit of interfering with the legal machinery of California whenever the interests of a Chinaman are involved. We can take care of ourselves and our Chinamen, too'. ${ }^{96}$

\section{Conclusion}

Baldwin was, jurisprudentially speaking, a very long shot indeed. The Chinese were calling on the court to resurrect a statute three years dead and buried, something rarely attempted in constitutional litigation. When the Chinese entered the legal lists, it was normally with firmer hopes of success. On the other hand, the times were parlous. It was urgent that some action be taken, and no other avenues of recourse seemed available. ${ }^{97}$ Initiating litigation, even on frail grounds, if it did nothing else, may at least have seemed to them to serve as a signal to white society that they did not intend

93. As reported in The Evening Post, March 22, 1887.

94. Sacramento Daily Record Union, March 9, 1887.

95. Daily Alta California, March 10, 1887.

96. San Francisco Evening Post, March 8, 1887.

97. It is significant to note that on the very day of the Nicolaus incident Owyang Ming, the Consul-General in San Francisco and Consul Bee had telegraphed Gov. George Stoneman of California, pleading that he take immediate action but had received a terse and completely non-committal reply. See H.R. Exec. Doc. 49th Cong., 2nd Sess., Vol. 1, Foreign Relations of the United States (1886), p. 158. 
to remain supine in the face of the ominous forces that threatened them. (It is worth noting that at the same time the Baldwin case was progressing through the courts, a group of Chinese merchants were pressing an action for damages for negligence in the Circuit Court against the city government of Eureka, California for failing to protect them and their property against a mob. ${ }^{98}$ ) And of course it must be remembered that, despite the odds, the Chinese in fact prevailed in the first phase of the litigation, and, that even though they lost on appeal, they did not come away completely emptyhanded. For one thing the court had made clear that it was reserving judgment on the question whether Sec. 5519 could be enforced in the territories. This was significant as some of the greatest outrages perpetrated against the Chinese, the Rock Springs massacre for example, had occurred in federal territories. Much more important, the court had declared unequivocally that it was entirely within the constitutional authority of the congress to enact legislation providing for the punishment of those who were guilty of depriving Chinese subjects of any of the rights of privileges that had been guaranteed them by treaty.

Baldwin was different, too, in respect of the Chinese legation's heavy involvement in the case. It was not the normal practice of the legation to involve itself in Chinese civil rights litigation. And yet the legation seems to have played a significant role in the launching and maintenance of the action. One does not have to look very far for an understanding of why it should be especially interested in this case. A major object of Chinese diplomacy at the time was to persuade the United States government to take forceful, direct action to protect Chinese subjects resident on its soil against mob violence. ${ }^{99}$ It was skeptical of American claims that the national government was powerless to do anything at all, and the action initiated by hopworker Sing offered a convenient way of testing the validity of the state department position. Though the Baldwin decision vindicated that position to the extent that it determined that certain federal laws were unavailable for the prosecution of anti-Chinese rioters (at least in the states), it completely undermined the implicit American claim that considerations of federalism forever precluded national government intervention of any sort. The legation was quick to point this out to the state department. On March 18, 1887, twelve days after the Supreme Court handed down its decision, the Chinese Minister left a communication at the State Department, which contained the draft of some provisions of a new treaty to be negotiated between China and the United States. The provisions envisioned a much more active role for the federal government in the protection of Chinese residents in America. In his gloss on the provisions the Minister suggested that Congress enact a law imposing the death penalty on anti-Chinese conspirators. The Supreme

98. See case file Wing Hing v. Eureka, File 3948, Federal Archives and Records Center, San Bruno, Ca.

99. See text and notes supra at pp. 355-56. 
Court in its Baldwin opinion, the Minister remarked, had sanctioned the spirit of his suggestions. ${ }^{100}$

The Supreme Court may have removed all constitutional obstacles in the way of federal legislation to protect the Chinese, but it could do nothing about the political obstacles in the way of such legislation. Congress was in no mood to consider any such measures. That body was coming under more and more pressure from western interests to enact stricter exclusion laws and was proving more and more willing to succumb to those pressures. Within a little over a year it would pass some of the harshest anti-Chinese measures ever enacted by any legislative body, including an act that abrogated the provisions of a treaty. ${ }^{101}$ The most lasting gain, then, that the Chinese might have hoped to get out of the Baldwin litigation failed to materialize. Fortunately, rioting and violence against the Chinese subsided somewhat toward the end of the decade, and the Congress, grudgingly and without admitting any liability, did eventually appropriate a total of some $\$ 425,000$ for the compensation of the survivors of the Rock Springs, Wyoming riot and of other anti-Chinese disturbances. The money was distributed to victims and survivors under the supervision of the San Francisco consulate.

100. Note left by the Chinese Minister, Chang Yin-huan, at the Department of State, March 18, 1887; H.R. Exec. Doc. No. Sec. 18 244, 50th Cong., 2nd Sess., Vol. 1, Foreign Relations of the United States (1888), pp. 368-69.

101. Sandmeyer, supra note 6 at $99-102$. 
HeinOnline -- 3 Law \& Hist. Rev. 3741985 